\title{
Pengembangan Learning Management System (LMS) di Era Pandemi Covid-19 pada Pendidikan Anak Usia Dini
}

\author{
Nur Ika Sari Rakhmawati ${ }^{\bowtie 1}$, Sjafiatul Mardliyah ${ }^{2}$, Ruqoyyah Fitri ${ }^{3}$, Darni ${ }^{4}$, Kisyani Laksono ${ }^{5}$ \\ Pendidikan Guru Pendidikan Anak Usia Dini, Universitas Negeri Surabaya, Indonesia $(1,3)$ \\ Pendidikan Luar Sekolah, Universitas Negeri Surabaya, Indonesia(2) \\ Pendidikan Bahasa Jawa, Universitas Negeri Surabaya, Indonesia(4) \\ Pendidikan Bahasa Indonesia, Universitas Negeri Surabaya, Indonesia(5) \\ DOI: $10.31004 /$ obsesi.v6i1.991
}

\begin{abstract}
Abstrak
Kondisi pandemi yang melanda hampir seluruh negara-negara yang ada di dunia, menyebabkan permasalahan pada dunia pendidikan khususnya pada proses pembelajaran. Oleh sebab itu, diperlukan sebuah media yang dapat mensinkronkan seluruh aktivitas pembelajaran. Tujuan inti dari penelitian ini adalah mengembangkan dan menguji kehandalan desain LMS bagi PAUD pada website SIKUMBANG. Menggunakan model pengembangan ADDIE. Subyek yang digunakan dalam ujicoba ini yaitu 3 orang guru dan 26 siswa Taman Kanak-Kanak Lab School Unesa. Hasil LMS yang telah dikembangkan dapat diakses pada laman https://sikumbang.unesa.ac.id. Selain itu dilakukan validasi perangkat yang digunakan dalam LMS dengan menggunakan metode survey yang dilakukan secara daring dengan dinilai sangat layak untuk digunakan. Pada tahap implement (implementasi) dilakukan sebanyak tiga kali pada tema keluarga. Berdasarkan hasil uji terdapat peningkatan jumlah pengguna. Pengguna dapat menggunakan secara mandiri, adanya komunikasi yang baik antara guru dan orang tua dalam pelaksanaan pembelajaran daring menggunakan LMS, guru dalam melaksanakan pembelajaran sesuai dengan tahap pembelajaran daring.
\end{abstract}

Kata Kunci: pembelajaran daring; website; lms.

\begin{abstract}
Pandemic conditions have almost hit all countries in the world, causing problems in the world of education, especially in the learning process. Therefore, we need a media that can synchronize all learning activities. The main objectives of this study are to develop and test the reliability of LMS design for early childhood education on the SIKUMBANG website. The research method used in this development uses the ADDIE development model. The subjects used in this trial were 3 teachers and 26 students of Kindergarten Lab School Unesa. The results of the LMS that have been developed can be accessed on the https://sikumbang.unesa.ac.id page. In addition, the validation of the devices used in the LMS was carried out using a survey method which was carried out online. According to the survey results, the SIKUMBANG LMS is considered very feasible to use. At the implementation stage, it was carried out three times on the theme of the family. Based on the results there is an increase in the number of users. Users can use independently, there is good communication between teachers and parents in implementing online learning using LMS, teachers in implementing learning according to the stage of online learning.
\end{abstract}

Keywords: online learning; website; lms.

Copyright (c) 2021 Nur Ika Sari Rakhmawati, Sjafiatul Mardliyah, Ruqoyyah Fitri, Darni, Kisyani Laksono

$\bowtie$ Corresponding author :

Email Address : nurrakhmawati@unesa.ac.id (Surabaya, Indonesia)

Received 21 December 2021, Accepted 20 March 2021, Published 1 April 202 


\section{PENDAHULUAN}

Pada masa pandemi covid-19, proses pembelajaran bagi anak usia dini sebagai upaya untuk meningkatkan capaian perkembangan anak mendorong lembaga PAUD untuk melaksanakan pembelajaran jarak jauh yang dilaksanakan berbasis rumah dengan menggunakan sistem online. Kondisi ini menuntut kerjasama orangtua dan sekolah secara maksimal. Pembelajaran di rumah mendorong orangtua mampu membimbing tugas yang diberikan oleh guru dan menyediakn fasilitas pembelajaran yang diperlukan (Lilawati, 2020). Keterlibatan orangtua dalam proses pembelajaran pada anak usia dini, berfungsi sebagai sekolah keluarga yang bertujuan untuk mengembangkan empati dan kreativitas anak usia dini (Mardliyah et al., 2020). Namun demikian, pandemi yang berlangsung hampir satu tahun melahirkan berbagai kendala seperti: minimnya pemahaman materi, kesulitan menumbuhkan minat belajar, mengatur waktu belajar karena orangtua harus bekerja, orang tua tidak sabar mendampingi anak belajar, pengetahuan yang kurang untuk menggunakan gadget, dan susahnya akses internet (Wardani \& Ayriza, 2020). Ada kendala faktor eksternal berupa media pembelajaran dan faktor internal yaitu kelelahan mendidik anakyang dihadapi orangtua selama masa school from home (Mufaziah \& Fauziah, 2020)

Solusi untuk menghadapi situasi di atas memerlukan peran administrator kepala sekolah agar penyelenggaraan pendidikan tetap berjalan di masa pandemi (Supriadi, 2020)Kepala sekolah harus mampu melakukan interaksi dengan guru dan orangtua menggunakan media online untuk mencipatkan rasa aman, kepuasan dan dapat menjalankan pembelajaran (Sudrajat et al., 2020). Dengan demikian dukungan tehnologi informasi berupa laptop maupun android agar pembelajaran tetap berjalan di masa pandemi tidak terelakkan. Pelaksanaan pembelajaran daring antara guru dan anak didik di lembaga PAUD harus berlangsung dalam waktu yang sama dan berada dalam sebuah aplikasi atau platform internet untuk melakukan interaksi satu dengan yang lainnya seperti halnya dalam pembelajaran tatap muka (Wijoyo \& Indrawan, 2020). Berkembangnya teknologi-informasi dan internet mendorong lahirnya pembelajaran yang dikenal dengan istilah e-learning yang memiliki konsep lebih luas daripada online learning. E-learning bisa berbasis computer atau disebut computer-based learning dan berbasis online learning yaitu pembelajaran dalam jaringan atau disebut Daring. Online learning bisa menggunakan internet yang dikenal dengan internetbased learning dan bias berbasis website yang dikenal dengan web-based learning yang keduanya menggunakan jaringan online yang saling terhubung terus menerus antara satu pengguna dengan pengguna yang lain. Sementara itu gabungan dari e-learning dan face-to-face learning secara offline disebut pembajaran campuran atau blended learning atau hybrid learning (Kraftl, 2013).

Dengan demikian pembelajaran pada pendidikan anak usia dini juga dapat dilaksanakan dengan menggunakan sistem informasi berbasis website yang saling berkaitan antar tampilan (Lestari et al., 2021). Namun demikian para pendidik di PAUD menemui kendala seperti: terbatasnya komunikasi, minimnya metode pembelajaran dan materi, biaya tinggi dan akses terhadap tehnologi antara pendidik dan orangtua yang tidak dapat dihindari (Agustin et al., 2020). Sementara itu berdasarkan observasi awal yang sudah dilakukan menunjukkan bahwa pemanfaatan media sosial berupa WhatsApp yang sudah dilaksanakan sejak awal masa pandemi dirasakan masih kurang efektif. Umumnya guru membuat grup WA wali murid yang berfungsi untuk memudahkan guru berkomunikasi dengan orang tua. Namun informasi yang diberikan pada grup WA tersebut hanya bersifat pengumuman atau pengganti surat cetak. Ketika ada kegiatan atau perayaan tertentu, orangtua mengirimkan foto atau video aktivitas anak ke sekolah. Interaksi melalui media ini dianggap kurang komunikatif sehingga dibutuhkan sistem pembelajaran daring yang lebih memadai.

Faktor inilah yang mendorong perlunya memanfaatkan pembelajaran online dengan mengggunakan aplikasi Moodle. Moodle adalah sebuah Open Source Course Management System (CMC), yang berarti tempat belajar dinamis dengan menggunakan model berorientasi objek. Perangkat tehnologi ini juga dikenal sebagai Learning Management System (LMS) atau 

DOI: 10.31004/obsesi.v6i1.991

Virtual Learning Environment (VLE). Moodle merupakan sebuah program aplikasi yang dapat merubah media pembelajaran ke dalam bentuk web. Manfaat dari pengunaan LMS menggunakan Moodle secara online sangat penting, diantaranya adalah mengatasi keterbatasan frekuensi tatap muka antara siswa dengan guru (Herayanti et al., 2017). Dipilihnya Learning Management System (LMS) ini karena pada masa pandemi Covid-19 proses pembelajaran di Pendidikan Anak Usia Dini (PAUD) tidak bisa mengumpulkan siswa dengan alasan keamanan. Sisi positif dilaksanakan School from Home dengan menggunakan Learning Management System mendorong orang tua untuk dapat aktif dalam pembelajaran anak dan melakukan pengamatan serta pemberian stimulasi perkembangan secara optimal meskipun ibunya bekerja.

Learning Management System (LMS) merupakan istilah dalam dunia teknologi yang dikembangkan secara khusus untuk mengelola dan menfasilitasi seluruh proses pembelajaran online. Aktivitas pembelajaran melalui LMS dapat dikembangkan melalui berbagai fitur yang meliputi proses pendaftaran, pembayaran, distribusi bahan pembelajaran, proses interaksi antara guru dan siswa dalam kelas virtual serta test online yang dilakukan menggunakan perangkat komputer dan android (Hidayat et al., 2017). Adapun beberapa fungsi LMS adalah publikasi materi pembelajaran, download materi pembelajaran, pemberian tugas dan penilaian (Muhson, 2010).

Uraian pada peryataan diatas, mendorong peneliti mengajukan pertanyaan bagaimana pengembangan desain Learning Management System dalam pembelajaran di PAUD? Dan bagaimana kelayakan desain Learning Management System dalam pembelajaran di PAUD? Tujuan penelitian adalah mengembangkan desain Learning Management System berbasis website dalam pelaksanaan pembelajaran di PAUD dan mengetahui kelayakan desain Learning Management System dalam pembelajaran di PAUD.

\section{METODOLOGI}

Penelitian pengembangan ini menggunakan model pengembangan ADDIE. Model ini dipilih karena, desain pengembangannya sederhana dan sistematis. Tim pengembang berfokus pada pengembangan desain serta menguji kelayakan learning management system (LMS) bagi PAUD pada website SIKUMBANG. Penelitian pengembangan ini dapat digambarkan pada bagan 1 .

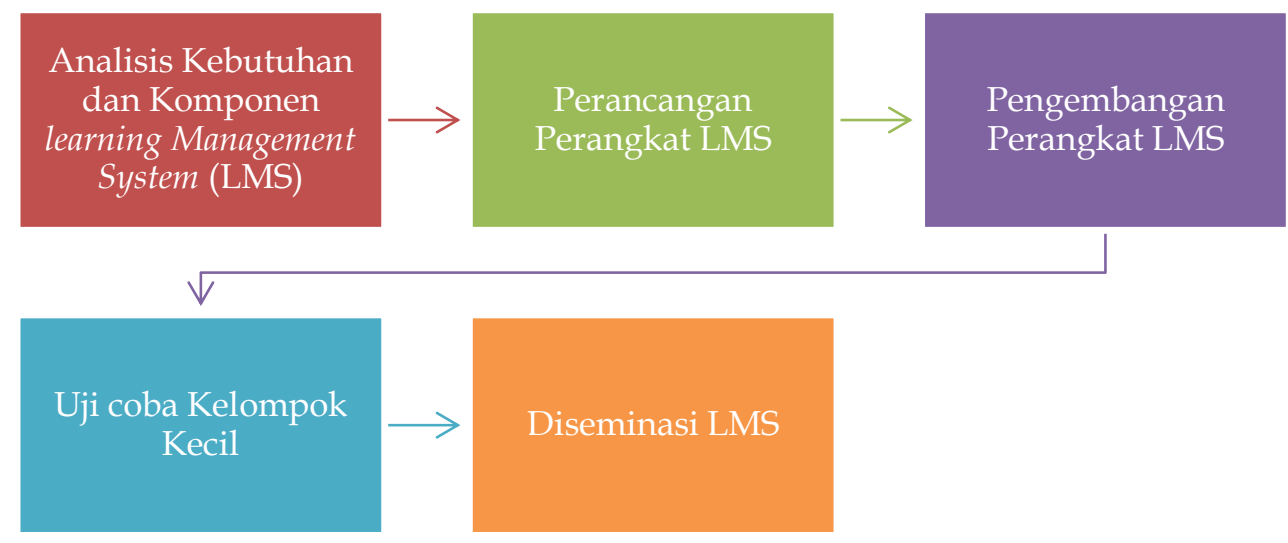

Bagan 1. Alur Penelitian Pengembangan LMS

Model ADDIE merupakan model pengembangan yang terdiri dari 5 tahap yaitu: Analysis, Design, Develop, Implement, Evaluate (evaluasi). Namun, dalam penelitian pengembangan di tahun ini dibatasi hanya pada tahap Implement pada kelompok kecil. Pada tahap analysis (analisis) terdiri dari dua kegiatan yaitu analisis kebutuhan dan analisis komponen perangkat learning management system (LMS) bagi PAUD dengan melakukan focus group discussion (FGD) antara tim pengembang dengan teman sejawat, praktisi PAUD serta 
stakeholder di PAUD, tahap design (perancangan) dimulai dari merencanakan perangkat learning management system (LMS) bagi PAUD yang cocok dan mudah digunakan, menyusun menu tampilan yang akan digunakan dalam perangkat LMS, menyusun rincian menu yang terdapat pada masing-masing tampilan, menentukan tema pembelajaran, merencanakan pembelajaran daring, mengembangkan sumber belajar daring, merancang ruang untuk melakukan pembelajaran sinkronus (web meeting) serta merancang tampilan untuk mengupload tugas.

Selanjutnya pada tahap pengembangan dilakukan pengisian pada menu di masingmasing tampilan, memasukkan rencana pembelajaran daring pada LMS, mengunggah sumber belajar daring yang digunakan, menyediakan ruang untuk melakukan pembelajaran sinkronus (web meeting). Selain itu dilakukan validasi materi untuk mengetahui apakah materi yang digunakan dalam learning management system (LMS) layak untuk digunakan atau tidak. Tahap selanjutnya adalah implement (implementasi) pada tahap ini yang dilakukan adalah uji coba penggunaan LMS pada kelompok kecil.S asaran uji coba penelitian pengembangan ini adalah guru, murid dan orangtua wali murid di TK Labschool Unesa.

Metode pengumpulan data yang digunakan dalam penelitian ini adalah metode observasi, wawancara dan survey. Observasi dilakukan untuk memeroleh data selama pelaksanaan uji coba penggunaan LMS. Saran observasi yaitu guru dan murid/orangtua, instrumen yang digunakan dalam observasi yaitu lembar pengamatan aktivitas guru dan murid/orangtua dalam menggunakan LMS. Wawancara digunakan untuk memeroleh data yang dibutuhkan dalam analisis kebutuhan dan analisis konten. Wawancara dilaksanakan secara daring, menggunakan platform google meet. Adapun sasaran dalam wawancara ini adalah akademisi dan praktisi PAUD. Sedangkan Survey, digunakan untuk menguji kehandalan produk LMS yang dikembangkan. Survey dilakukan secara online dengan menggunakan google form yang akan disebar kepada ahli materi dan perangkat serta pengguna LMS (guru, murid/orangtua).

\section{HASIL DAN PEMBAHASAN}

Penelitian pengembangan ini dilaksanakan melalui model pengembangan ADDIE, adapun hasil pada masing-masing tahapan sebagai berikut :

\section{Tahap Analisis}

Tahap analisis dilakukan untuk mengetahui kebutuhan konten dan komponen perangkat learning management system (LMS)bagi PAUD, hasil analisis awal yang dilakukan oleh tim pengembang komponen perangkat yang harus ada dalam LMS SIKUMBANG terdapat pada table 1.

Selain itu tim pengembang juga melakukan analisis kebutuhan konten dan komponen learning management system (LMS) bagi PAUD melalui kegiatan focus group discussion (FGD) antara tim pengembang dengan 3 teman sejawat yang berasal dari unsur dosen, praktisi PAUD serta stakeholder di lembaga PAUD. Focus Group Discussion (FGD) bersama guru TK Idhata yang dilaksanakan secara daring menggunakan platform zoom.

Pada tahap awal FGD ini, peneliti dan bunda PAUD menjelaskan dengan detail latar belakang dan urgensi diadakan penelitian ini setelah paparan selesai tim pengembang melakukan wawancara dengan para akademisi dan praktisi PAUD. Kegiatan ini bertujuan agar terdapat kesepahaman dan kesepakatan sebelum melaksanakan validasi dan uji coba. Berdasarkan hasil wawancara yang dilakukan kepada para akademisi dan praktisi PAUD mendapatkan hasil dan masukan sebagai berikut : (1) akses untuk login di LMS agar dipermudah paling tidak harus dapat diakses menggunakan android, (2) guru dan orang tua yang dalam hal ini sebagai pengguna LMS harus diberikan pemahaman agar dapat menggunakan LMS secara mandiri, (3) tampilan LMS perlu dibuat lebih menarik agar lebih cocok untuk sasaran penelitian yaitu anak usia 4-6 tahun, (4) aplikasi ini bagus dan dapat membantu guru untuk mengadministrasikan program-program sekolah. 
Tabel 1. Komponen Learning Management System (LMS) Bagi PAUD

\begin{tabular}{|c|c|c|}
\hline Tampilan & Komponen & Uraian \\
\hline $\begin{array}{l}\text { Menu } \\
\text { Admin }\end{array}$ & $\begin{array}{ll}\text { 1. Halaman login } \\
\text { 2. Halaman profil } \\
\text { 3. Halaman master } \\
\text { data } \\
\text { 4. Halaman } \\
\text { learning } \\
\text { managemen } \\
\text { system (LMS) }\end{array}$ & $\begin{array}{l}\text { 1. Halaman admin yang bertugas mengoperasionalkan adalah } \\
\text { tenaga kependidikan (petugas administrasi / TU) Pada halaman } \\
\text { login terdapat username dan password yang digunakan untuk } \\
\text { mengakses website SIKUMBANG. } \\
\text { 2. Halaman profil berisi tentang identitas petugas administrasi } \\
\text { yang diberitugas untuk mengoperasionalkan halaman website } \\
\text { pada menu admin. } \\
\text { 3. Halaman master data digunakan untuk memasukkan data-data } \\
\text { admin, guru dan siswa. } \\
\text { 4. Halaman learning management system (LMS) digunakan oleh } \\
\text { admin untuk mengatur seluruh kebutuhan LMS (enroll status } \\
\text { pengguna, menyediakan ruang diskusi, menyediakan ruang } \\
\text { untuk merencanakan pembelajaran, menyediakan ruang untuk } \\
\text { melakukan pembelajaran sinkronus dalam sistem LMS, serta } \\
\text { menyediakan ruang untuk mengunggah tugas). }\end{array}$ \\
\hline $\begin{array}{l}\text { Menu } \\
\text { Guru }\end{array}$ & $\begin{array}{l}\text { 1. Halaman login } \\
\text { 2. Halaman profil } \\
\text { 3. Halaman } \\
\text { pembelajaran } \\
\text { 4. Halaman LMS } \\
\text { guru } \\
\text { 5. Halaman } \\
\text { penilaian }\end{array}$ & $\begin{array}{l}\text { 1. Menu guru disediakan untuk guru kelas / guru pendamping } \\
\text { masing-masing kelas. Pada halaman login terdapat username dan } \\
\text { password yang digunakan untuk mengakses website } \\
\text { SIKUMBANG. } \\
\text { 2. Halaman profil berisi tentang identitas guru yang bertanggung } \\
\text { jawab pada satu kelas tertentu. } \\
\text { 3. Halaman pembelajaran berisikan informasi kegiatan semester, } \\
\text { mingguan atau harian yang akan diterima oleh anak-anak. } \\
\text { 4. Halaman LMS bagi guru digunakan guru untuk menyediakan } \\
\text { rencana pembelajaraan daring, menyediakan sumber belajar } \\
\text { daring serta mengoreksi hasil pekerjaan anak. } \\
\text { 5. Halaman penilaian berisi informasi capaian hasil perkembangan } \\
\text { anak baik itu harian, bulanan maupun semester, menggunakan } \\
\text { bentuk penilaian ratting scale, catatan anekdot dan penilaian } \\
\text { portofolio anak. }\end{array}$ \\
\hline $\begin{array}{l}\text { Menu } \\
\text { Siswa } \\
\text { (Ortu) }\end{array}$ & $\begin{array}{l}\text { 1. Halaman login } \\
\text { 2. Halaman profil } \\
\text { 3. Halaman layanan } \\
\text { 4. Halaman LMS } \\
\text { siswa } \\
\text { 5. Halaman laporan } \\
\text { 6. Halaman timeline }\end{array}$ & $\begin{array}{l}\text { 1. Menu siswa yang mengoperasionalkan adalah orangtuwa / wali } \\
\text { murid. Pada halaman login terdapat username dan password yang } \\
\text { digunakan untuk mengakses website SIKUMBANG. } \\
\text { 2. Halaman profil disediakan untuk menuliskan identitas siswa. } \\
\text { Mulai dari nama lengkap, nama panggilan, foto, nama orangtua, } \\
\text { pekerjaan orangtua, alamat, jumlah saudara, sampai ciri-ciri } \\
\text { fisik. Profil tersebut dibutuhkan sekolah untuk kelengkapan } \\
\text { identitas anak. } \\
\text { 3. Halaman layanan berisi tentang layanan-layanan yang diterima } \\
\text { anak di sekolah. Adapun menu yang ada pada halaman layanan } \\
\text { antara lain : pendidikan, pengasuhan, kesehatan dan gizi. } \\
\text { 4. Halaman LMS siswa berisi kegiatan pembelajaran yang akan } \\
\text { diikuti oleh siswa secara daring serta menguploap tugas yang } \\
\text { diberikan oleh guru. } \\
\text { 5. Halaman laporan berisi tentang laporan hasil capaian } \\
\text { perkembangan anak di sekolah. Adapun laporan ini akan } \\
\text { diberikan setiap hari slesai kegiatan pembelajaran yang } \\
\text { dirangkum dalam format pelaporan harian, serta ditafsirkan } \\
\text { pada pelaporan bulanan dan semesteran. } \\
\text { 6. Halaman timeline dibuat agar orang tua dapat melihat } \\
\text { dokumentasi baik itu foto maupun video ketika anak } \\
\text { berkegiatan di sekolah. Disamping itu pada halaman ini orang } \\
\text { tua diberikan wadah untuk berkonsultasi dengan pihak sekolah } \\
\text { terkait perkembangan anak di sekolah maupun di rumah. }\end{array}$ \\
\hline
\end{tabular}

Tahap Desain

Pada tahap desain atau perancangan, tim pengembang merencanakan LMS bagi PAUD dengan fitur-fitur sebagai berikut; (1) Perencanaan kegiatan pembelajaran, fitur ini 
disediakan agar guru dapat mempersiapkan bahan ajar dan merancang kegiatan pembelajaran secara daring. Fitur ini dapat berfungsi untuk mengorganisasikan seluruh perencanaan, bahan ajar yang digunakan serta pelaksanaan kegiatan pembelajaran dapat dilakukan secara tersistem, (2) Kegiatan pembelajaran secara sinkronus, fitur ini disediakan agar guru dapat menyapa anak-anak serta melaksanakan kegiatan pembelajaran secara daring/virtual menggunakan platform google meet yang langsung ditautkan dalam LMS, (3) Fitur unggah tugas siswa, fitur ini disediakan agar memudahkan orang tua untuk mengumpulkan tugas yang telah diselesaikan oleh anak selain itu juga fitur ini sangat membantu guru dalam mengorganisasikan dan menilai seluruh hasil belajar anak, (4) Jurnal mengajar guru, fitur ini disediakan agar guru dapat mencatat seluruh aktivitas yang telah dilakukan pada hari itu yang dimana hasil dari jurnal mengajar dapat dijadikan acuan/perbaikan untuk pelaksanaan pembelajaran selanjutnya.

\section{Tahap Pengembangan}

Pada tahap pengembangan saat ini tim pengembang telah selesai mengembangkan learning management system (LMS) bagi PAUD pada laman https://sikumbang.unesa.ac.id/ berdasarkan saran dari para akademisi dan prktisi PAUD pada saat pelaksanaan FGD. Adapun tampilan LMS sikumbang dapat dilihat pada gambar $1-4$.

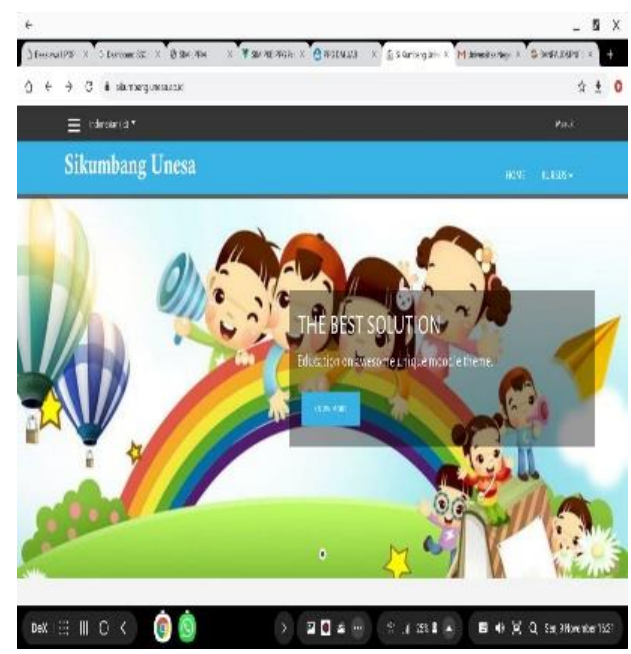

Gambar 1. Tampilan Awal LMS Sikumbang

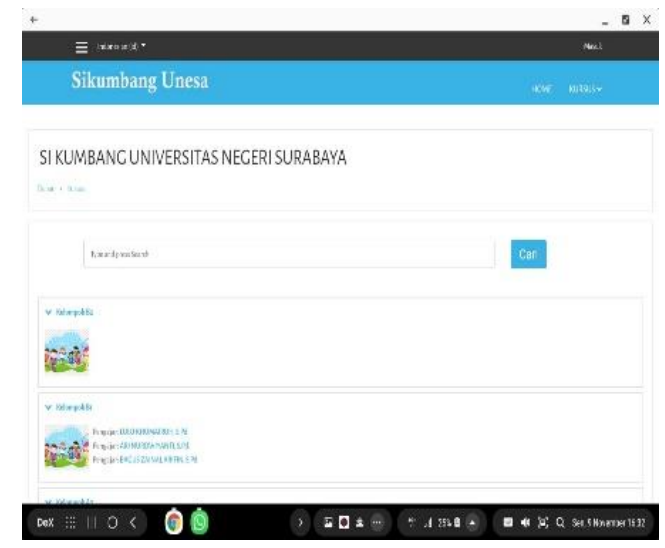

Gambar 3. Tampilan Menu Pilihan Kelas yang Disediakan di LMS

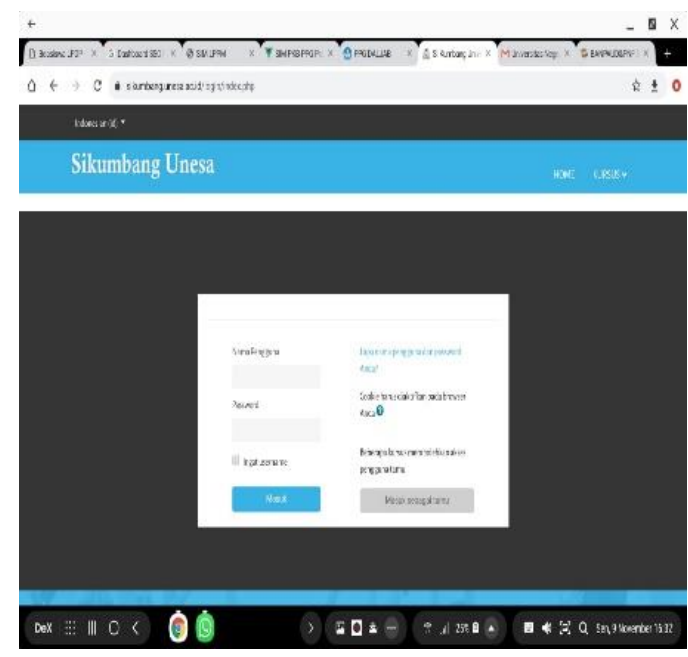

Gambar 2. Halaman Login LMS Sikumbang.

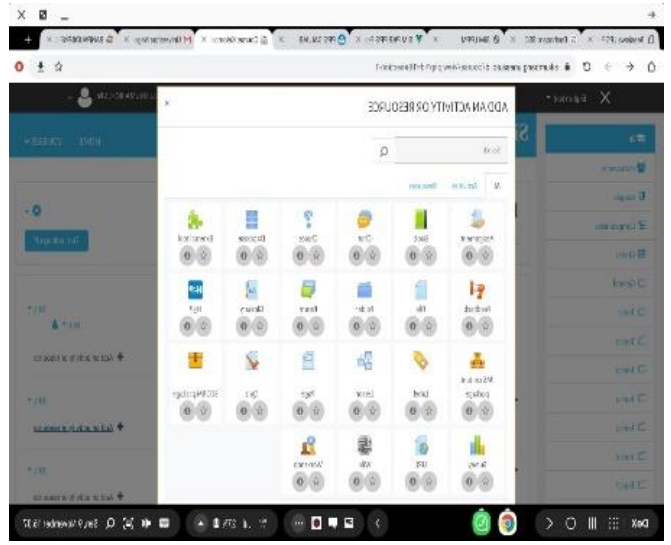

Gambar 4. Tampilan Untuk Menambah Aktivitas dalam LMS

Selain itu, tim pengembang juga melakukan uji kehandalan produk LMS SIKUMBANG dengan menggunakan metode survey yang dilakukan secara daring menggunakan google form kepada 2 orang ahli PAUD dan 2 orang praktisi PAUD. Pada survey 
ini menyediakan 7 item pertanyaan dengan skala penilaian $1-5$, score maximal yang diperoleh dalam kelayakan adalah 35. Butir item yang digunakan dalam uji kelayakan LMS, antara lain; tampilan, kelengkapan menu, kemudahan akses, kejelasan, kemudahan dalam penggunaan, menu yang tersedia dalam LMS. Adapun hasil survey terdapat pada tabel 2.

Tabel 2. Rekap Hasil Survey Kelayakan LMS

\begin{tabular}{clcc}
\hline No & \multicolumn{1}{c}{ Validator } & Score & Keterangan \\
\hline 1 & Validator Ahli & 27 & Layak Digunakan \\
2 & Validator Ahli & 31 & Sangat Layak Digunakan \\
3 & Guru & 31 & Sangat Layak Digunakan \\
4 & Guru & 23 & Cukup Layak Digunakan \\
\hline
\end{tabular}

\section{Tahap Implementasi}

Sebelum pelaksanaan uji coba pembelajaran daring menggunakan LMS Sikumbang, terlebih dahulu tim pengembang memberikan arahan dan bimbingan kepada guru-guru TK LAB SCHOOL Unesa (TK IDHATA) agar dapat menggunakan LMS secara mandiri. Materi yang disampaikan pada pembimbingan tersebut, mulai dari cara masuk LMS, mengubah paswaord, merencanakan kegiatan pembelajaran daring, menyiapkan bahan ajar, mengunggah bahan ajar pada LMS, menyediakan link web meet untuk pelaksanaan pembelajaran daring secara sinkronus, serta menyediakan tautan untuk unggah tugas. Pada tahap implementasi dilakukan uji coba terbatas sebanyak 3 kali, pada tema keluarga. Subyek uji coba ke 1 dilakukan kepada 3 guru dan 10 siswa, uji coba ke 2 sebanyak 3 guru dan 15 siswa sedangkan uji coba ke 3 dilakukan kepada 3 guru dan 26 siswa. Adapun hasil uji coba 1 - 3, dijelaskan sebagai berikut:

\section{a. Implementasi Uji Coba 1}

Setelah mengetahui Langkah-langkah menggunakan LMS, tahapan berikutnya adalah menyusun rencana belajar daring yang akan dilakukan oleh siswa. Dikarenakan pada pekan/minggu ke 15 sudah mulai masuk ke dalam kegiatan pengayakan, maka tema yang dipilih adalah tema keluarga. Adapun sub-sub tema yang dipilih adalah tentang keluarga inti, mengenal kakek dan nenek, dan juga mengenal keluarga besar. Setelah ditentukan sub-sub temanya, kemudian tim Guru Menyusun rancangan kegiatan yang akan dilaksanakan pada masing-masing sub tema. Adapun rancangan kegiatan belajar daring pada uji coba ke 1 pada tabel 3.

Tabel 3. Rancangan kegiatan pada topik 1 / uji coba ke 1

\begin{tabular}{ll}
\hline Tema & Keluarga ( Sub tema Keluarga Inti ) \\
Kegiatan topik 1 / uji & 1) Mengenal arti keluarga inti \\
coba 1 direncanakan & 2) Mengenal siapa saja anggota keluarga inti dan juga perannya \\
& 3) Menonton video yang bercerita tentang keluarga. \\
& 4) Membuat roncean gelang manik-manik untuk ibu \\
\hline
\end{tabular}

Setelah menyusun rencana kegiatan yang akan dilaksanakan pada topik 1, guru menyiapkan sumber dan bahan belajar yang akan digunakan saat pembelajaran daring menggunakan LMS Sikumbang. Sumber dan bahan belajar yang telah disiapkan oleh guru adalah manik-manik dan benang serta video pembelajaran dan video tutorial. Manik-manik dan benang telah dipacking dan dibagikan kepada orang tua pada saat drive thru. Sedangkan untuk video pembelajaran tentang keluarga inti dan video tutorial cara membuat gelang manik-manik untuk ibu ku diunggah di LMS pada topic 1.

Setelah mengunggah bahan belajar, guru menyediakan link web meet yang akan digunakan pada saat pelaksanaan pembelajaran sinkronus, serta menyediakan tautan untuk mengunggah tugas/hasil belajar yang telah dilakukan oleh siswa pada topik 1 . Setelah 
menyiapkan bahan belajar pada LMS, guru mengundang wali murid secara daring untuk mensosialisasikan dan memberikan arahan terkait penggunaan LMS. Materi yang disampaikan oleh guru kepada wali murid, antara lain; guru menyampaikan maksud dan tujuan dilaksanakan sosialisasi, menunjukkan laman LMS Sikumbang, memberitahukan cara login, mengubah pasword, mengakses seluruh bahan ajar yang telah disiapkan serta memberitahukan cara mengunggah tugas yang telah dilakukan oleh anak.

Setelah melakukan sosialisasi terkait cara penggunaan LMS, guru membuat kesepakatan dengan orang tua, untuk itu orang tua diminta mengakses seluruh bahan ajar serta bergabung pada web meet melalui link yang telah disediakan dalam LMS. Uji coba ke 1 ini dilakukan kepada 10 anak, yang hasilnya 10 anak tersebut telah mengakses bahan belajar yang telah disediakan oleh guru pada LMS, mengakses link web meet dari LMS serta 9 anak mengunggah tugas dalam LMS dengan tepat waktu. Adapun 1 anak yang tidak mengunggah tugas dengan tepat waktu ini disebabkan karena akun LMS anak tersebut mengalami kendala.

\section{b. Implementasi Uji Coba 2}

Implementasi uji coba ke 2 dilaksanakan dengan subyek sasaran sebanyak 15 siswa. Adapun hasil yang didapatkan pada implementasi uji coba ke 2. Sebelum guru melaksanakan pembelajaran daring pada topik 2 / uji coba ke 2 terlebih dahulu guru merancang kegiatan pembelajaran, rencana kegiatan yang disusun sebagaimana pada tabel 4 .

Tabel 4. Rancangan kegiatan pada topik 2 / uji coba ke 2

\begin{tabular}{|c|c|}
\hline Tema & Keluarga ( Sub tema Kakek dan Nenek ) \\
\hline Kegiatan topik 2 / uji & 1) Mengenal arti kakek dan nenek \\
\hline coba 2 direncanakan & 2) Mengenal peran kakek dan nenek \\
\hline & 3) Menggunting dan menghias baju nenek dengan borci \\
\hline
\end{tabular}

Setelah menyusun rancangan pelaksanaan pembelajaran harian yang akan dilaksanakan pada topik 2, guru menyiapkan sumber dan bahan ajar yang akan digunakan saat pembelajaran daring menggunakan LMS Sikumbang. Sumber dan bahan ajar yang telah disiapkan oleh guru adalah kertas lipat yang sudah tersedia gambar pola baju nenek, borci, lem rajawali, video pembelajaran tentang peran kakek dan nenek serta video tutorial cara menghias baju nenek. kertas lipat yang sudah tersedia gambar pola baju nenek, borci dan lem rajawali telah dipacking dan dibagikan kepada orang tua pada saat drive thru. Sedangkan untuk video pembelajaran tentang peran kakek dan nenek diunggah di LMS pada topic 2.

Setelah mengunggah bahan belajar, guru menyediakan link web meet yang akan digunakan pada saat pelaksanaan pembelajaran sinkronus, serta menyediakan tautan untuk mengunggah tugas / hasil belajar yang telah dilakukan oleh siswa pada topic 2. Setelah menyiapkan sumber dan bahan ajar, guru memberikan informasi kepada orang tua melalui chat pada WA grup wali murid tentang pelaksanaan web meet uji coba ke 2. Orang tua diminta untuk mengakses seluruh bahan ajar dan mengikuti web meet menggunakan tautan link yang telah disediakan dalam LMS.

Uji coba ke 2 ini dilakukan kepada 15 anak, yang hasilnya 15 anak tersebut telah mengakses bahan belajar yang telah disediakan oleh guru pada LMS, mengakses link web meet dari LMS serta 15 anak mengunggah tugas dalam LMS dengan tepat waktu.

\section{c. Implementasi Uji Coba 3}

Implementasi uji coba ke 3 dilaksanakan dengan subyek sasaran sebanyak 31 siswa. Adapun hasil yang didapatkan pada implementasi uji coba ke 3 yaitu; sebelum guru melaksanakan pembelajaran daring pada topic 3 / uji coba ke 3 terlebih dahulu guru merancang kegiatan pembelajaran (tabel 5).

Tabel 5. Rancangan kegiatan pada topik 2 / uji coba ke 2 


\begin{tabular}{ll}
\hline Tema & Keluarga ( Sub tema Anggota Keluarga Besar) \\
Kegiatan topik 3 / uji & 1) Mengenal Anggota Keluarga Besar \\
coba 3 direncanakan & 2) Menonton video tutorial tentang cara membuat pigura \\
& 3) Membuat pigura dengan menggunakan kertas koru - koru \\
\hline
\end{tabular}

Setelah menyusun rencana kegiatan yang akan dilaksanakan pada topik 3, guru menyiapkan sumber dan bahan belajar yang akan digunakan saat pembelajaran daring menggunakan LMS Sikumbang. Sumber dan bahan belajar yang telah disiapkan oleh guru adalah kertas koru-koru dan lem rajawali serta video pembelajaran dan video tutorial. Kertas koru-koru dan lem rajawali telah dipacking dan dibagikan kepada orang tua pada saat drive thru. Sedangkan untuk video pembelajaran tentang keluarga inti dan video tutorial cara membuat gelang manik-manik untuk ibu ku diunggah di LMS pada topik 3.

Setelah mengunggah bahan belajar, guru menyediakan link web meet yang akan digunakan pada saat pelaksanaan pembelajaran sinkronus, serta menyediakan tautan untuk mengunggah tugas / hasil belajar yang telah dilakukan oleh siswa pada topic 3. Setelah menyiapkan sumber dan bahan ajar, guru memberikan informasi kepada orang tua melalui chat pada WA grup wali murid tentang pelaksanaan web meet uji coba ke 3. Orang tua juga diminta untuk mengakses seluruh bahan ajar dan mengikuti web meet menggunakan tautan link yang telah disediakan dalam LMS.

Uji coba ke 3 dilakukan kepada 26 anak, yang hasilnya 26 anak tersebut telah mengakses bahan belajar yang telah disediakan oleh guru pada LMS, mengakses link web meet dari LMS serta 26 anak mengunggah tugas dalam LMS dengan tepat waktu. Berdasarkan hasil uji coba 1 - 3 menunjukkan bahwa, terdapat peningkatan jumlah pengguna learning management system (LMS) SIKUMBANG, adanya komunikasi yang baik antara guru dan orang tua dalam pelaksanaan pembelajaran daring menggunakan LMS, guru dalam melaksanakan pembelajaran daring sesuai dengan tahapan yaitu persiapan, pengorganisasian, pelaksanaan serta evaluasi, pengguna LMS dapat melakukan seluruh tahapan secara mandiri, dan juga para siswa yang dalam hal ini dibantu oleh orang tua juga mengunggah tugas pada LMS sesuai dengan waktu yang diberikan oleh guru. Hasil peningkatan pengguna, dapat digambarkan pada grafik 1 .

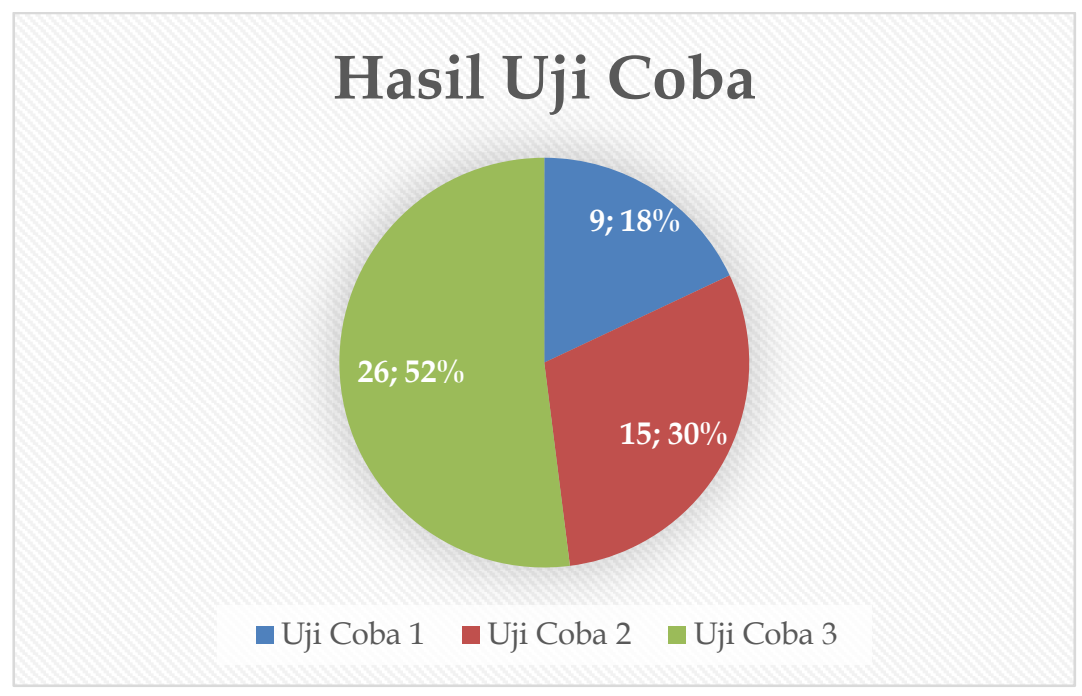

Grafik 1. Perbandingan Hasil Uji Coba 1 - 3

Setelah pelaksanaan uji coba terbatas sebanyak 3 kali selesai dilaksanakan, maka tim pengembang kembali melakukan survey kelayakan secara online menggunakan google form. 
Kepada pengguna yaitu 3 guru dan perwakilan 13 wali murid, adapun hasil kelayakan setelah uji coba didapatkan data pada tabel 6.

Tabel 6. Rekap Hasil Survey Kelayakan LMS Setelah Uji coba

\begin{tabular}{llcc}
\hline No. & Validator & Score & Keterangan \\
\hline 1 & Guru & 31 & Sangat Layak Digunakan \\
2 & Guru & 23 & Cukup Layak Digunakan \\
3 & Guru & 32 & Sangat Layak Digunakan \\
4 & Walimurid & 26 & Layak Digunakan \\
5 & Walimurid & 21 & Cukup Layak Digunakan \\
6 & Walimurid & 27 & Layak Digunakan \\
7 & Walimurid & 29 & Layak Digunakan \\
8 & Walimurid & 29 & Layak Digunakan \\
9 & Walimurid & 30 & Layak Digunakan \\
10 & Walimurid & 30 & Layak Digunakan \\
11 & Walimurid & 30 & Layak Digunakan \\
12 & Walimurid & 31 & Sangat Layak Digunakan \\
13 & Walimurid & 28 & Layak Digunakan \\
14 & Walimurid & 30 & Layak Digunakan \\
15 & Walimurid & 32 & Sangat Layak Digunakan \\
16 & Walimurid & 35 & Sangat Layak Digunakan \\
\hline
\end{tabular}

Hasil uji kelayakan, apakah desain LMS layak digunakan atau tidak dapat disimpulkan pada interval berikut : 15 - 20 Tidak layak digunakan, 21 - 25 cukup layak digunakan, 26 - 30 layak digunakan, 31 - 35 sangat layak digunakan. Berdasarkan tabel, guru dan wali murid yang memberikan penilaian LMS dengan kategori cukup layak sebanyak 2 orang, dan 9 orang memberikan penilaian pada kategori layak digunakan sedangkan 5 orang memberikan penilaian pada kategori sangat layak digunakan. Untuk itu dapat diputuskan bahwa desain LMS yang dikembangkan layak untuk digunakan.

\section{Pembahasan}

Pengembangan learning management system (LMS) bagi PAUD, dilaksanakan menggunakan model pengembangan ADDIE. Namun di tahun ke 1 ini pengembangannya hanya sampai tahap uji coba terbatas yang dilaksanakan sebanyak 3 kali. Pada tahap analisis, dilakukan analisis konten dan komponen perangkat LMS. Pada analisis konten yang dibutuhkan adalah seluruh perangkat pembelajaran yang digunakan dalam pembelajaran daring harus sesuai dengan pengguna, sedangkan untuk analisis komponen perangkat didapatkan hasil menu yang dibutuhkan dalam LMS adalah menu untuk admin, guru dan siswa. Pada masing-masing menu terdapat fitur yang berbeda-beda.

Pada menu admin, terdapat fitur untuk management kursus, mulai dari membuat kelas pada LMS, menentukan jumlah topic/pertemuan yang direncanakan, membuat menu untuk guru serta membuat menu untuk siswa. Menu untuk guru, terdapat fitur untuk, merencanakan kegiatan pembelajaran daring, menyediakan bahan ajar yang dapat diakses oleh siswa kapan saja dan dimana saja, menyediakan komunitas belajar online menggunakan pembelajaran synkronus dan asynkronus. Guru juga dapat menyediakan menu untuk unggah tugas, hal ini dimaksudkan agar hasil belajar siswa dapat dilihat sewaktu-waktu dan tersimpan dalam sebuah system pembelajaran, guru juga dapat langsung memberikan penilaian serta memberikan feedback pada hasil belajar harian siswa. Desain LMS telah memiliki fitur pendaftaran, komunitas belajar online, kelas virtual, dan tes online. Hal ini menunjukkan bahwa LMS telah memenuhi fitur dan fungsi, fitur publikasi materi pembelajaran, fungsi download, fitur penugasan atau latihan, dan fitur penilaian.

Uji kelayakan dilakukan kepada ahli dan pengguna LMS (guru dan wali murid) dengan jumlah 18 orang. Uji kelayakan dilakukan dengan cara menyebar angket kelayakan 
secara online menggunakan link google form, waktu pelaksanaan uji kelayakan dilakukan sebelum uji coba dan setelah uji coba. Pada angket uji kelayakan terdapat 7 item pertanyaan dengan skala penilaian 1 - 5. Score maximal yang diperoleh untuk uji kelayakan adalah 35 . Hasil uji kelayakan, apakah desain LMS layak digunakan atau tidak dapat disimpulkan pada interval berikut : 15 - 20 Tidak layak digunakan, 21 - 25 cukup layak digunakan, 26 - 30 layak digunakan, 31 - 35 sangat layak digunakan. Hasil uji kelayakan menunjukkan bahwa, dari 18 orang $11 \%$ menyatakan LMS cukup layak digunakan, $22 \%$ menyatakan sangat layak digunakan dan 66 \% menyatakan layak digunakan. Untuk itu dapat disimpulkan bahwa desain LMS layak untuk digunakan pada uji coba pada skala yang lebih besar.

Implementasi pembelajaran daring menggunakan learning management system (LMS) pada PAUD di TK LAB SCHOOL Unesa (TK IDHATA) dilakukan sebanyak 3 kali. Sasaran atau subyek uji coba dalam penelitian ini adalah guru dan siswa kelompok B yang berusia 5 6 tahun yang dalam hal ini dibantu oleh orang tua atau pendamping untuk mengakses pembelajaran daring yang sudah direncanakan oleh guru. Jumlah subyek pada uji coba ke 1 sebanyak 10 anak, uji coba ke 2 sebanyak 15 anak sedangkan pada uji coba ke 3 dilakukan pada 26 anak. Tahapan uji coba dimulai dari guru merencanakan kegiatan pembelajaran daring, karena pada minggu ke 13 kegiatan pembelajarannya adalah pengayaan maka tema yang dipilih pada pelaksanaan uji coba adalah tema keluarga. Setelah merencanakan kegiatan, guru menyiapkan sumber dan bahan ajar yang akan digunakan dalam uji coba, sumber dan bahan ajar yang disiapkan oleh guru pada uji coba 1 sampai 3 adalah, video pembelajaran, manik-manik, benang senar, kertas lipat, kertas kokoru, kancing baju, dan lem rajawali.

Setelah guru menyiapkan sumber dan bahan ajar, maka guru membagikan sumber dan bahan ajar tersebut kepada siswa yang akan melaksanakan uji coba. Guru juga mengarahkan siswa dengan bantuan orangtua wali murid untuk mengakses LMS pada laman https//sikumbang.unesa.ac.id, pada laman tersebut siswa dapat mengakses bahan ajar yang berupa video pembelajaran, mengikuti pembelajaran secara virtual menggunakan google meet, serta mengunggah tugas yang telah diberikan oleh guru. Temuan ini sejalan hasil penelitian yang menyatakan bahwa LMS dapat menyediakan sarana untuk interkoneksi yang lebih baik dengan orang tua kepada siswa, LMS dapat menyediakan infrastruktur untuk semua tugas, anak-anak juga dapat menggunakan kontent yang telah disiapkan oleh guru asalkan terdapat komunikasi dan kolaborasi yang baik antara guru dan orang tua (Dias \& Diniz, 2013).

Kelemahan penelitian jika dipandang dari paradigma pengelolaan PAUD memiliki kekurangan yaitu tidak bisa menyajikan permainan atau pembelajaran sambil bermain. Karena dalam pembelajaran di PAUD menggunakan LMS tidak memberikan kesempatan kepada anak untuk melakukan itu. Akan tetapi, pengembangan LMS telah memenuhi empat fungsi manajemen yaitu perencanaan, pengorganisasian, pelaksanaan serta evaluasi (Aryani et al., 2020). Berdasarkan penjelasakan tersebut dapat disimpulkan bahwa pengembangan LMS telah sesuai dengan fungsi manajemen pembelajaran namun tetap harus didasarkan pada prinsip pembelajaran di PAUD.

\section{SIMPULAN}

Terdapat peningkatan jumlah pengguna learning management system (LMS) SIKUMBANG, pengguna dapat menggunakan secara mandiri. Adanya komunikasi yang baik antara guru dan orang tua dalam pelaksanaan pembelajaran daring menggunakan LMS. Guru dalam melaksanakan pembelajaran telah sesuai dengan tahap pembelajaran daring.

\section{UCAPAN TERIMA KASIH}

Kami haturkan terimakasih yang sebesar-besarnya kepada rektor dan ketua LPPM Universitas Negeri Surabaya yang telah memberikan kesempatan kepada kami untuk melakukan penelitian penugasan pada tahun anggaran 2020. Teman-teman guru dan orang 
tua wali murid di TK IDHATA yang telah memberikan ruang bagi tim peneliti sehingga mendapatkan informasi dan membantu menyelesaikan penelitian ini.

\section{DAFTAR PUSTAKA}

Agustin, M., Puspita, R. D., Nurinten, D., \& Nafiqoh, H. (2020). Tipikal Kendala Guru PAUD dalam Mengajar pada Masa Pandemi Covid 19 dan Implikasinya. Jurnal Obsesi : Jurnal Pendidikan Anak Usia Dini, 5(1), 334. https://doi.org/10.31004/obsesi.v5i1.598

Aryani, N., Mudjiran, \& Rakimahwati. (2020). The learning management model of early childhood education program based on children development. International Journal of Scientific and Technology Research, 9(1), 86-91.

Dias, S. B., \& Diniz, J. A. (2013). FuzzyQoI model: A fuzzy logic-based modelling of users' quality of interaction with a learning management system under blended learning. Computers and Education, 69, 38-59. https://doi.org/10.1016/j.compedu.2013.06.016

Herayanti, L., Habibi, H., \& Fuaddunazmi, M. (2017). Pengembangan Media Pembelajaran Berbasis Moodle pada Matakuliah Fisika Dasar. Jurnal Cakrawala Pendidikan, 36(2), 205209. https://doi.org/10.21831/cp.v36i2.13077

Hidayat, H., Hartono, \& Sukiman. (2017). Pengembangan Learning Management System (LMS) untuk Bahasa Pemrograman PHP. Jurnal Ilmiah Core IT: Community Research $\begin{array}{lll}\text { Information } & \text { Technology, 20-29. }\end{array}$ http:/ / www.ijcoreit.org/index.php/coreit/article/viewFile/11/11

Kraftl, P. (2013). Beyond "voice", beyond "agency", beyond "politics"? Hybrid childhoods and some critical reflections on children's emotional geographies. Emotion, Space and Society, 9(1), 13-23. https://doi.org/10.1016/j.emospa.2013.01.004

Lestari, R. H., Sumitra, A., Nurunnisa, R., \& Fitriawati, M. (2021). Perancangan Perencanaan Pembelajaran Anak Usia Dini Melalui Sistem Informasi Berbasis Website. 5(2), 1396-1408. https://doi.org/10.31004/obsesi.v5i2.770

Lilawati, A. (2020). Peran Orang Tua dalam Mendukung Kegiatan Pembelajaran di Rumah pada Masa Pandemi. Jurnal Obsesi: Jurnal Pendidikan Anak Usia Dini, 5(1), 549. https://doi.org/10.31004/obsesi.v5i1.630

Mardliyah, S., Yulianingsih, W., \& Putri, L. S. R. (2020). Sekolah Keluarga: Menciptakan Lingkungan Sosial untuk Membangun Empati dan Kreativitas Anak Usia Dini. Jurnal Obsesi: Jurnal Pendidikan Anak Usia Dini, 5(1), 576. https://doi.org/10.31004/obsesi.v5i1.665

Mufaziah, E., \& Fauziah, P. (2020). Kendala Orang Tua dalam Mendidik Anak Usia Dini pada Saat Pandemi Covid 19. Jurnal Obsesi : Jurnal Pendidikan Anak Usia Dini, 5(2), 1045-1051. https://doi.org/10.31004/obsesi.v5i2.746

Muhson, A. (2010). Pengembangan Media Pembelajaran Berbasis Teknologi Informasi. Jurnal Pendidikan Akuntansi Indonesia, 8(2). https:// doi.org/10.21831/jpai.v8i2.949

Sudrajat, C. J., Agustin, M., Kurniawati, L., \& Karsa, D. (2020). Strategi Kepala TK dalam Meningkatkan Mutu Pendidikan pada Masa Pandemi Covid 19. Jurnal Obsesi : Jurnal Pendidikan Anak Usia Dini, 5(1), 508. https://doi.org/10.31004/obsesi.v5i1.582

Supriadi, O. (2020). Peranan Kepala PAUD dalam Penyelenggaraan Pendidikan Sebelum dan Saat Terjadi Pandemi Covid-19. Jurnal Obsesi : Jurnal Pendidikan Anak Usia Dini, 5(1), 841-856. https://doi.org/10.31004/obsesi.v5i1.727

Wardani, A., \& Ayriza, Y. (2020). Analisis Kendala Orang Tua dalam Mendampingi Anak Belajar di Rumah Pada Masa Pandemi Covid-19. Jurnal Obsesi : Jurnal Pendidikan Anak Usia Dini, 5(1), 772. https://doi.org/10.31004/obsesi.v5i1.705

Wijoyo, H., \& Indrawan, I. (2020). Model Pembelajaran Menyongsong New Era Normal Pada Lembaga Paud Di Riau. JS (Jurnal Sekolah) Universitas Negeri Medan, 4(3), 205-212. https://doi.org/10.24114/js.v4i3.18526 